\title{
Structured literature review on organizational innovation in family business context
}

\author{
Shekhar Suman \\ Indian Institute of Management (IIM) Raipur, India
}

Satyasiba Das

Indian Institute of Management (IIM) Raipur, India

\begin{abstract}
Over the past decade, research on innovation in family firms has shown incremental growth. Several scholars and practitioners across the globe have shown interest in this field, which has also enriched the current body of literature. Despite the growth in studies related to innovation, research lacks a comprehensive review of the past and present achievements. In our study, we tried to fulfill this gap with a focus on family and firms' influence on organizational innovation. Based on a systematic review of 30 plus journal articles, it presents an integrative picture of family firm innovation. Major research avenues have been discussed based on which areas of future research can be determined.
\end{abstract}

Keywords

Family business, innovation, family factor, firm factor

\section{Introduction}

The importance of innovation has already been realized in the business domain and in recent past, it has gained momentum in family businesses too. Innovation being the most important factor for economic prosperity and sustainable growth has become the need of the hour (Porter, 1979). The vision of continuity and transgenerational succession being vital characteristics of the family business has developed a need for innovation study in this domain (Chua, Chrisman, \& Sharma, 1999). The majority of research compared family firms with their non-family counterparts, showing the former as less innovation than the latter. Authors show that family involvement and control in businesses are a few of the major factors to influence the innovation process. Duran, Kammerlander, Van Essen, \& Zellweger (2016) shows that though family businesses invest less in innovation, they do it more efficiently. To understand the family firms' multi-staged innovation activities better, it is necessary to study elements that differ from family firms to nonfamily firms (Duran et. al., 2016). Though many studies have been conducted, we still lack a comprehensive overview of innovation in family firms and this literature review is a try to fill this gap. We would review the effect of family and firm characteristics on innovation. The insights from this review can open doors to future research in the domain of family business innovation. Along with the researchers, practitioners can also benefit from this review by linking family business characteristics with innovation.

The article has been designed to cover the conceptual background of the topic, the methodology for selection of papers, the literature review on family factors and the firms' characteristics and their influence on the organizational innovation process, and conclusion that covers findings, limitations, and scope for future research. The article also presents a tabular form of journals of selected papers for this review. 


\section{Conceptual background}

\subsection{Innovation process}

The innovation process has been defined as the process of generating and adopting new or improved products, processes, policies, structures or administrative systems (Damanpour, 1991). De Massis, Frattini, \& Lichtenthaler (2013) have explained the innovation process in three steps of input, activity, and output. The innovation input stage is concerned with investment in Research and Development (R\&D) and in employees related to innovation. The innovation activity stage covers the aspects of resource allocation, organizational culture, learning process, and knowledge management. In the last stage, innovation output describes the radical or incremental innovation in product, process, administration or business model. Moreover, Lumpkin, Steier, \& Wright (2011) write about contextual parameters of firms such as geographical location, size, family ownership, company structure, industry size, and governance. that can affect the firm's innovativeness.

\subsection{Family business and innovation}

The role of the family system in a family business is the most important parameter to study any phenomena in the setting of the family business (Zachary, 2011). Family businesses have been looked upon as social systems that couple business families with the business i.e. the ability of the family to influence business premises via communicating their decisions that would affect the future of the firm; also known as Luhmann's new systems theory (Luhmann, 1995). Few other concepts like socioemotional wealth and familiness form a resource-based platform to study innovation in the family business. Popescu \& Andrei (2011) has analyzed the impact of Common Agriculture Policy on promoting family farms in Romanian agrarian economy. Though the family farms would not succeed in providing good economic performance, but it can satisfy the consumption needs. The paper shows the importance of strong relationship among community members and socioemotional wealth over financial gain. Patel \& Fiet (2011) have explained long-term orientation, tacit knowledge, strong family bonds and social network as few factors that influence family firm's ability to innovate. Even startups showed great prospects for growth and value creation to their customers through implementation of innovative digital platforms (Ruggieri, Savastano, Scalingi, Bala, \& D'Ascenzo, 2018). Our approach in this article is to study the holistic approach of ability, willingness and control of family over businesses and the approach towards innovation. Chrisman, Chua, De Massis, Frattini, \& Wright (2015) has studied the importance of economic and noneconomic goals across family firms over innovativeness and found that it depends upon various factors such as governance structure, resources, and idiosyncratic situational aspects. However, the family businesses that are involved in multi-levels of innovation enjoy sustainable growth and profit across generations (Sharma \& Salvato, 2011).

\section{Methodology for paper selection}

The goal of our systematic review is to identify ongoing themes in the family business innovation domain and to find out the significant research gaps. For a systematic review of the literature, the first step is to develop criteria for selecting research papers and articles. The next step of the literature review is keyword selection. Keyword searches were made over numerous databases such as EBSCO, Google Scholar, Pro-Quest, Science Direct, and Emerald. The timeframe of the search was majorly from 2011 to 2017 with few old seminal works. Keywords, as Family Firms, Innovation, Innovation Process, Family System were used for refining and narrowing the search criteria for classifying papers. The early databank was further refined to identify research papers that match the research questions and aims. Once the research papers and articles were identified, the references of the papers were used for identifying additional papers, an approach termed as 'snowball sampling'. Thirty-two articles/research papers were recognized based on predefined primary keywords using various search engines and databases combined. Table 1 shows the categorization of the journals based on the above classification and ranked by the number of papers used in this review. 
Table 1 List of referred journals

\begin{tabular}{l|l|c}
\hline S. No. & Name of the Journal & No. of Papers \\
\hline 1 & Entrepreneurship Theory and Practice & 5 \\
\hline 2 & Family Business Review & 4 \\
\hline 3 & Journal of Product Innovation Management & 4 \\
\hline 4 & Academy of Management Journal & 2 \\
\hline 5 & Journal of Family Business Strategy & 2 \\
\hline 6 & Asia Pacific Journal of Management & 1 \\
\hline 7 & California Management Review & 1 \\
\hline 8 & Family Business Management & 1 \\
\hline 9 & Harvard Business Review & 1 \\
\hline 10 & International Journal of Business, Management and Social Sciences & 1 \\
\hline 11 & International Journal of Entrepreneurial Behavior and Research & 1 \\
\hline 12 & Introduction to The Theory of The Family Business & 1 \\
\hline 13 & Journal of Family Business Management & 1 \\
\hline 14 & Journal of Business Ethics & 1 \\
\hline 15 & Journal of Small Business Management & 1 \\
\hline 16 & Management Decision & 1 \\
\hline 17 & Review of Managerial Science & 1 \\
\hline 18 & Strategic Entrepreneurship Journal & 1 \\
\hline 19 & Small Business Economics & 1 \\
\hline 20 & Stanford University Press & \\
\hline
\end{tabular}

\section{Review}

\subsection{Family firms' factors influencing the innovation process}

Firms with ownership of only one generation are more efficient in converting innovation into high performance compared to firms with several generations due to intergenerational conflicts (Kellermanns, Eddleston, Sarathy, \& Murphy, 2012). Family firms seem to invest a lot in R\&D when there is a low overlap between family wealth and firm equity (Sciascia, Nordqvist, Mazzola, \& De Massis, 2015). Family members tend to take the risk for innovation when their wealth is not at stake and this has resulted in a positive relationship between family involvement and R\&D investment in emerging economies (Ashwin, Krishnan, \& George, 2015).

Classen, van Gils, Bammens, \& Carree (2012) found that family firms rely less on external resources and show less faith in innovation cooperation or collaborations. This behavior can have both positive as well as a negative impact on innovation. However, this behavior ceases to exist once the firms find strong protection mechanisms like copyrights and patent filings for their innovation (Kotlar, De Massis, Frattini, Bianchi, \& Fang, 2013). The vision for innovation, whether radical or incremental influences the strategic decisions of the firm. The firms that try to handle exploitation and exploration simultaneously are defined as ambidextrous firms
(O'Reilly \& Tushman, 2004). Few of the past studies found the correlation between the degree of ownership by family members in the top management team (TMT) and the propensity to innovate. Family involvement in leadership roles and their risk-taking abilities influence the innovation process in firms (Kraiczy, Hack, \& Kellermanns, 2015). The middle and lower-level employees also become a part of informal innovation activities by their feelings of obligation, motivation and perceived organizational support (Bammens, Notelaers, \& Van Gils, 2015). The family businesses try to reduce the uncertainty by developing new business models in succession. Llach, Marquès, Bikfalvi, Simon, \& Kraus (2012) studied the effect of the recession on the family business innovation process and found that during recession family firms reduce the amount of investment in R\&D activities compared to nonfamily firms. One of the papers revealed an interesting fact that the presence of the family name in the firm's name generates heavy stock returns while introducing a new innovative product into the market compared to family firms that do not use the family names (Kashmiri \& Mahajan, 2014). Kraus, Pohjola, \& Koponen (2012) found that these results are attributable to the geographical differences and the investor's perception of the family firms. Also, we found that family businesses are more prone to 
incremental innovation, but it might be the consequences of the industry in which family firm operates and also the demand of the customers (Grundström, Öberg, \& öhrwall Rönnbäck, 2012; Hiebl, 2015)

\subsection{Family factors influencing the innovation process}

If the families have long-term orientation and ambition to forward entrepreneurial acumen through generations, then the firms will invest in innovation processes such as in $R \& D$ activities and hire innovative professionals. regardless of their success in product development and launch (Cassia, De Massis, \& Pizzurno, 2011; 2012). The paper also reveals that the family's intention to protect the longevity of the business sometime might result in risk aversion and thus low investment in innovation activities. On the other hand, Litz \& Kleysen (2001) found that incumbent family members in the businesses promote intergenerational innovation by permitting their successors to experiment on innovation and that results in the formation of relevant competencies in the succeeding generations. The impact of family's control over innovation activities reduces agency costs and support for better strategic moves but at times unquestioned and complete authority of the family might lead to lack of personnel with sufficient qualification for innovational activities and biases in decision making (De Massis, Kotlar, Frattini, Chrisman, \& Nordqvist, 2015). This leads to nepotism where all the crucial employee positions are filled by family members irrespective of their qualification and that results in a demotivated workforce (Miller, Wright, Le Breton-Miller, \& Scholes, 2015). Shared family visions and goals in a family firm have a positive impact on innovation (Craig, Dibrell, \& Garrett, 2014), i.e. family members that share the same values have a high level of communication and cohesiveness among them and that results in successful organizational innovation activities (Cassia De Massis, \& Pizzurno, 2011). Whereas family conflicts show a negative impact on the organizational innovation process where family members are not in a condition to understand, recognize or exploit each other's knowledge related to innovation (Chirico \& Salvato, 2016). The family values and vision lead to competitive advantage for the firms and that depends on the degree of influence family has on business through the implementation of business decisions and also the business's willingness to accept them (Frank, Kessler, Rusch, Suess-Reyes, \& Weismeier-Sammer, 2017).

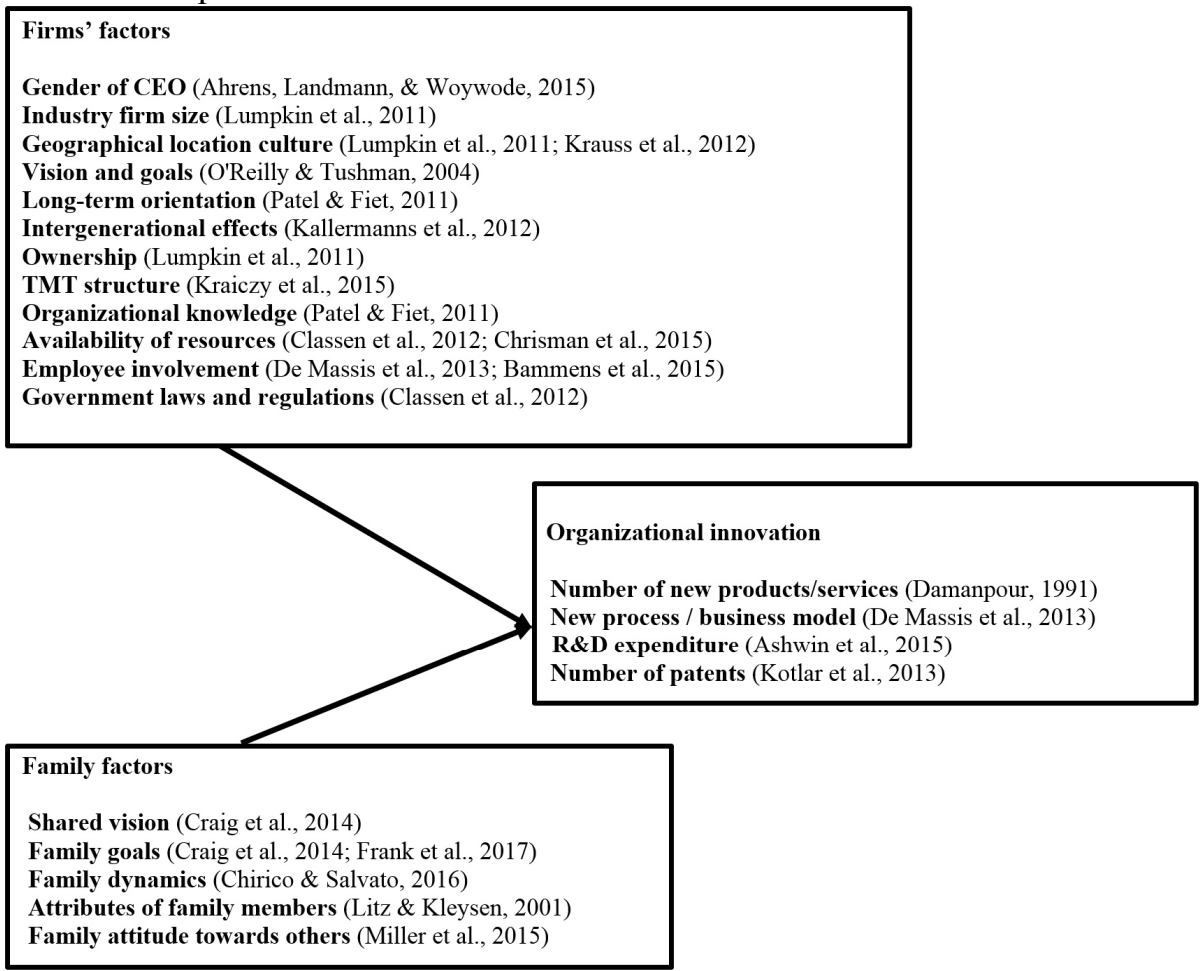

Figure 1 Conceptual framework of family's and firm's interaction with organizational innovation Source: Developed by the authors 


\section{Conclusion}

Drawing on to the perspective of new system theory, this literature review presents a holistic overview of the family business and innovation process. We tried to contribute by studying both the family and firms' factors and their influence on innovation. The interaction found from the existing literature has been shown in Figure 1. Through several articles discussed we found that familiness in businesses has both advantages and disadvantages for the adoption and implementation of the innovation process. Based on our personal observation, research literature on family business is very complex and that limits its scope for practical implications. Our article contributed to the family business research domain by summarizing the structures and findings of previous literature that are easy to understand and applicable in the practical sense. Family managers can benefit from the knowledge of family and firms' factors and their influence over the innovation process. Like other articles, this literature also has a few limitations. The innovation process discussed here does not clearly differentiate between innovation creation and adoption along with other innovation processes. The review also fails to include the perspective of family firm entrepreneurship in the innovation system.

The review has opened many areas for future research. It would be interesting to study factors such as skills of R\&D personnel, human resources, capabilities, knowledge and their influence over the innovation process. Research on a different kind of innovation such as process, product, and administration. can be encouraged. Scant research is observed in family dynamics and how it interacts with innovation. The presence of spouses, siblings and parents in the family and their influence over organizational innovation by their direct or indirect involvement in business can be a good area for future research. The last, but one of the most interesting aspects that can be attended to in future research is the effect of gender on innovation in family firms.sm

\section{References}

Ahrens, J. P., Landmann, A., \& Woywode, M. (2015). Gender preferences in the CEO successions of family firms: Family characteristics and human capital of the successor. Journal of Family Business Strategy, 6(2), 86-103.

https://doi.org/10.1016/j.jfbs.2015.02.002
Ashwin, A. S., Krishnan, R. T., \& George, R. (2015). Family firms in India: family involvement, innovation and agency and stewardship behaviors. Asia Pacific Journal of Management, 32(4), 869-900. https://doi.org/10.1007/s10490-015-9440-1

Bammens, Y., Notelaers, G., \& Van Gils, A. (2015). Implications of Family Business Employment for Employees' Innovative Work Involvement. Family Business Review, 28(2), 123-144. https://doi.org/10.1177/0894486513520615

Cassia, L., De Massis, A., \& Pizzurno, E. (2011). An exploratory investigation on NPD in Small Family Businesses from Northern Italy. International Journal of Business, Management and Social Sciences, 2(2), 114.

Cassia, L., De Massis, A., \& Pizzurno, E. (2012). Strategic innovation and new product development in family firms: An empirically grounded theoretical framework. International Journal of Entrepreneurial Behaviour and Research, 18(2), 198-232.

https://doi.org/10.1108/13552551211204229

Chirico, F., \& Salvato, C. (2016). Knowledge Internalization and Product Development in Family Firms: When Relational and Affective Factors Matter. Entrepreneurship: Theory and Practice, 40(1), 201-229. https://doi.org/10.1111/etap.12114

Chrisman, J. J., Chua, J. H., De Massis, A., Frattini, F., \& Wright, M. (2015). The ability and willingness paradox in family firm innovation. Journal of Product Innovation Management, 32(3), 310-318. https://doi.org/10.1111/jpim.12207

Chua, J. H., Chrisman, J. J., \& Sharma, P. (1999). Defining the Family Business by Behavior. Entrepreneurship Theory and Practice, 23(4), 19-39. https://doi.org/10.1177/104225879902300402

Classen, N., van Gils, A., Bammens, Y., \& Carree, M. (2012). The Search Breadth of Family SMEs. Journal of Small Business Management, 50(2), 191-215. https://doi.org/10.1111/j.1540-627X.2012.00350.x

Craig, J. B., Dibrell, C., \& Garrett, R. (2014). Examining relationships among family influence, family culture, flexible planning systems, innovativeness and firm performance. Journal of Family Business Strategy, 5(3), 229-238. https://doi.org/10.1016/j.jfbs.2013.09.002

Damanpour, F. (1991). Organizational Innovation : A MetaAnalysis of Effects of Determinants and Moderators Author ( $s$ ): Fariborz Damanpour Source: The Academy of Management Journal, Vol . 34 , No . 3 ( Sep ., 1991 ), pp . 555-590 Published by: Academy of Management Stable. Academy of Management, 34(3), 555-590. https://doi.org/10.5465/256406

de Massis, A., Frattini, F., \& Lichtenthaler, U. (2013). Research on Technological Innovation in Family Firms: Present Debates and Future Directions. Family Business Review, 26(1), 10-31. https://doi.org/10.1177/0894486512466258

De Massis, A., Kotlar, J., Frattini, F., Chrisman, J. J., \& Nordqvist, M. (2015). Family Governance at Work: Organizing for New Product Development in Family SMEs. Family Business Review, 29(2), 189-213. https://doi.org/10.1177/0894486515622722 
Duran, P., Kammerlander, N., Van Essen, M., \& Zellweger, T. (2016). Doing more with less: Innovation input and output in family firms. Academy of Management Journal, 59(4), 1224-1264. https://doi.org/10.5465/amj.2014.0424

Frank, H., Kessler, A., Rusch, T., Suess-Reyes, J., \& Weismeier-Sammer, D. (2017). Capturing the Familiness of Family Businesses: Development of the Family Influence Familiness Scale (FIFS). Entrepreneurship: Theory and Practice, 41(5), 709-742. https://doi.org/10.1111/etap.12229

Grundström, C., Öberg, C., \& öhrwall Rönnbäck, A. (2012) Family-owned manufacturing SMEs and innovativeness: A comparison between within-family successions and external takeovers. Journal of Family Business Strategy, 3(3), 162-173. https://doi.org/10.1016/j.jfbs.2012.07.001

Hiebl, M. R. W. (2015). Family involvement and organizational ambidexterity in later-generation family businesses: A framework for further investigation. Management Decision, 53(5), 1061-1082. https://doi.org/10.1108/MD-04-2014-0191

Kashmiri, S., \& Mahajan, V. (2014). A Rose by Any Other Name: Are Family Firms Named After Their Founding Families Rewarded More for Their New Product Introductions? Journal of Business Ethics, 124(1), 8199.

https://doi.org/10.1007/s10551-013-1861-5

Kellermanns, F. W., Eddleston, K. A., Sarathy, R., \& Murphy, F. (2012). Innovativeness in family firms: A family influence perspective. Small Business Economics, 38(1), 85-101. https://doi.org/10.1007/s11187-010-9268-5

Kotlar, J., De Massis, A., Frattini, F., Bianchi, M., \& Fang, H. (2013). Technology acquisition in family and nonfamily firms: A longitudinal analysis of spanish manufacturing firms. Journal of Product Innovation Management, 30(6), 1073-1088. https://doi.org/10.1111/jpim.12046

Kraiczy, N. D., Hack, A., \& Kellermanns, F. W. (2015). What makes a family firm innovative? CEO risk-taking propensity and the organizational context of family firms. Journal of Product Innovation Management, 32(3), 334-348. https://doi.org/10.1111/jpim.12203

Kraus, S., Pohjola, M., \& Koponen, A. (2012). Innovation in family firms: An empirical analysis linking organizational and managerial innovation to corporate success. Review of Managerial Science, 6(3), 265-286. https://doi.org/10.1007/s11846-011-0065-6

Litz, R. A., \& Kleysen, R. F. (2001). Your Old Men Shall Dream Dreams, Your Young Men Shall See Visions: Toward a Theory of Family Firm Innovation with Help from the Brubeck Family. Family Business Review, 14(4), 335-351. https://doi.org/10.1111/j.1741-6248.2001.00335.x
Llach, J., Marquès, P., Bikfalvi, A., Simon, A., \& Kraus, S. (2012). The innovativeness of family firms through the economic cycle. Journal of Family Business Management, 2(2), 96-109. https://doi.org/10.1108/20436231211261853

Luhmann, N. (1995). Social System. Series on Contemporary China. https://doi.org/10.1142/9789813206700 0009

Lumpkin, G. T., Steier, L., \& Wright, M. (2011). in Family Business Business and Strategic. Strategic Entrepreneurship Journal, 306, 285-306. https://doi.org/10.1002/sej

Miller, D., Wright, M., Le Breton-Miller, I., \& Scholes, L. (2015). Resources and innovation in family businesses: The Janus-face of socioemotional preferences. California Management Review, 58(1), 20-40. https://doi.org/10.1525/cmr.2015.58.1.20

Patel, P. C., \& Fiet, J. O. (2011). Knowledge combination and the potential advantages of family firms in searching for opportunities. Entrepreneurship: Theory and Practice, 35(6), 1179-1197. https://doi.org/10.1111/j.1540-6520.2011.00497.x

Popescu, G., \& Andrei, J. (2011). From industrial holdings to subsistence farms in the Romanian agriculture. Analyzing the subsistence components of the CAP. Agricultural Economics, 57(11), 555-564. https://doi.org/10.17221/72/2010-agricecon

Porter, M. E. (1979). How competitive forces shape strategy. Harvard Business Review, 137-135. https://doi.org/10.1097/00006534-199804050-00042

Ruggieri, R., Savastano, M., Scalingi, A., Bala, D., \& D'Ascenzo, F. (2018). The impact of Digital Platforms on Business Models: An empirical investigation on innovative start-ups. Management and Marketing, 13(4), 1210-1225. https://doi.org/10.2478/mmcks-2018-0032

Sciascia, S., Nordqvist, M., Mazzola, P., \& De Massis, A. (2015). Family ownership and R\&D intensity in smalland medium-sized firms. Journal of Product Innovation Management, 32(3), 349-360. https://doi.org/10.1111/jpim.12204

Sharma, P., \& Salvato, C. (2011). Commentary: Exploiting and exploring new opportunities over life cycle stages of family firms. Entrepreneurship: Theory and Practice, 35(6), 1199-1205. https://doi.org/10.1111/j.15406520.2011.00498.x

Zachary, R. K. (2011). The importance of the family system in family business. Journal of Family Business Management, 1(1), 26-36. https://doi.org/10.1108/20436231111122263 


\section{$\square$ Correspondence}

\section{Shekhar Suman}

PhD Scholar, Strategic Management

Indian institute of Management (IIM) Raipur

Atal Nagar (Naya Raipur), P. O. - Kurru (Abhanpur)

Raipur, PIN - 493 661, State - Chhattisgarh, India

Ph: +917024780949

E-mail:shekhar.fpm2015@iimraipur.ac.in 